\title{
PENGARUH VARIASI TEMPERATURE DAN HOLDING TIME PACK CARBURIZING MENGGUNAKAN MEDIA ARANG SERBUK GERGAJI KAYU JATI TERHADAP PENINGKATAN SIFAT MEKANIS BAJA KARBON RENDAH UNTUK MATERIAL PISAU
}

\author{
Nila Nurlina ${ }^{1)}$, Rahayu Mekar Bisono ${ }^{3)}$, Dani Irawan ${ }^{3)}$ \\ 1,2,3) Program Studi Teknik Mesin, Politeknik Negeri Malang \\ Email: nila24.ppm@gmail.com ${ }^{1)}$ \\ Indonesia
}

\begin{abstract}
ABSTRAK
Penurunan mutu baja yang disebabkan berbagai hal merupakan permasalahan yang sering terjadi dalam dunia industri. Baja yang beredar di pasaran mempunyai sifat lelah yang berbeda-beda. Sifat lelah tersebut mempengaruhi umur pakai baja. Peningkatan sifat mekanis dan fisis dilakukan untuk meningkatkan umur pakai baja menjadi dengan menggunakan berbagai teknik rekayasa sifat fisis dan mekanis. Tujuan dari penelitian ini adalah untuk mendapatkan komposisi tepat dari baja karbon rendah yang dapat diimplementasikan untuk pembuatan pisau TTG (Teknologi Tepat Guna) yang tajam namun tidak gampang patah. Penelitian ini dilaksanakan di Laboratorium Material Politeknik Negeri Malang di Kota Kediri. Variabel penelitian ini adalah suhu, waktu penahanan, media carburizing. Sedangkan sampelnya adalah suhu $850^{\circ} \mathrm{C}, 900^{\circ} \mathrm{C}$, dan $950^{\circ} \mathrm{C}$, waktu penahanan 30 menit, 60 menit, dan 90 menit, serta media carburizing serbuk gergaji kayu jati. Variabel tetap yang dipakai yaitu baja karbon rendah dan media carburizing arang serbuk gergaji kayu jati. Sedangkan variabel bebasnya adalah variasi temperature dan holding time. Hasil penelitian ini menunjukkan bahwa nilai uji kekerasan tertinggi terdapat pada holding time 30 menit dengan temperature carburizing $950^{\circ} \mathrm{C}$ yaitu $180.1 \mathrm{HRB}$ (Hardness Rockwell B). Sedangkan nilai uji kekerasan terendah terdapat pada holding time 90 menit dengan temperature carburizing yaitu 177.1 HRB (Hardness Rockwell B).
\end{abstract}

Kata kunci: material pisau, arang gergaji kayu jati, temperatur, waktu penahanan.

\section{ABSTRACT}

The decline of steel quality due to various things is a problem that often occurs in the industrial world. Steel on the market has different fatigue properties. The fatigue properties affect the service life of steel. Improvements in mechanical and physical properties are carried out to increase steel durability by using various physical and mechanical properties engineering techniques. This research aims to find the exact composition of low carbon steel that can be implemented to manufacture TTG (Appropriate Technology) knives that are sharp but not quickly broken. This research was conducted at the Material Laboratory of the State Polytechnic of Malang in Kediri. The variables of this research are temperature, holding time, carburizing media. While the samples are set on temperatures of 8500C, 9000C, and 9500C, respectively, having the time of 30 minutes, 60 minutes, and 90 minutes and teak sawdust carburizing media. At the same time, the independent variables are variations in temperature and holding time. The results of this study indicate that the highest hardness test value is found in the holding time of 30 minutes with a carburizing temperature of 9500C, namely 180.1 HRB (Hardness Rockwell B). Meanwhile, the lowest hardness test value was found at a holding time of 90 minutes with a carburizing temperature of 177.1 HRB (Hardness Rockwell B).

\section{Keywords: blade material, teak saw charcoal, temperature, holding time.}

\section{PENDAHULUAN}

Perkembangan pembangunan di Negara Indonesia mengalami peningkatan yang cukup signifikan. Hal ini juga menjadi salah satu faktor peningkatan taraf hidup masyarakat dalam bidang UMKM dan TTG (teknologi tepat guna). Penerapan teknologi tepat guna pada saat ini dilakukan dengan cara mencari alternatif material terbarukan yang mampu mengurangi dampak lingkungan.

Dengan adanya hal tersebut, bidang industri manufaktur mengalami pergeseran pengembangan. Hal tersebut dibuktikan dengan banyaknya penelitian dan penerapan di dunia industri yang memanfaatkan bahan alam untuk memperbaiki sifat fisik dan mekanik pada baja. Industri manufaktur peralatan baja mengalami peningkatan signifikan yang didukung oleh adanya isu global mengenai dampak lingkungan, dimana penggunaan plastik diganti dengan bahan baja.

Isu tersebut membawa dampak pada kebutuhan masyarakat dari sektor user sampai pabrikan seperti dalam pembuatan TTG, komponen otomotif, dan peralatan ataupun bahan baku lain dari baja. Luasnya kebutuhan baja dalam kehidupan 
sehari-hari mengakibatkan peran penting baja menjadi tidak dapat dihindari. Seiring dengan hal tersebut, dewasa ini juga masih ditemukan berbagaimacam permasalahan terkait dengan baja. Permasalahan yang sering dikhawatirkan dalam dunia industri adalah penurunan mutu baja yang disebabkan berbagai hal. Baja yang beredar di pasaran mempunyai sifat lelah yang berbeda-beda. Sifat lelah tersebut mempengaruhi umur pakai baja. Menurut Akita dan Tokaji (2006), peningkatan umur pemakaian baja dapat dilakukan dengan upaya peningkatan sifat fisik dan mekanik baja. Perbaikan tersebut salah satunya dapat dilakukan dengan teknik rekayasa permukaan material.

Material penyusun baja terdiri dari besi dan karbon. Baja memiliki kandungan karbon sekitar 0,1 - 2,0 \%. Unsur karbon merupakan unsur penting dalam pembentukan baja. Di samping itu, baja juga mengandung unsur yang mempengaruhi sifat baja. Selain karbon, unsur lain yang terdapat dalam baja adalah fosfor, sulfur, mangan dan silikon yang memiliki jumlah terbatas. Tujuan penambahan unsur campuran ini adalah untuk meminimalisasi pengaruh karbon pada baja itu sendiri. Untuk mendapatkan sifat lain dari paduan baja tersebut, maka dibutuhkan sejumlah unsur campuran lain (Surdia dan Saito, 1992). Komposisi Baja karbon pada umumnya terdiri dari paduan antara $\mathrm{Fe}$ (besi) dan $\mathrm{C}$ (karbon) dengan kadar karbon paling tinggi mencapai 2,14\%. Pada dasarnya baja karbon merupakan paduan dari berbagaimacam unsur di luar Fe, seperti Si, Mn, P, S, $\mathrm{N}$, dan $\mathrm{H}$, yang memberikan pengaruh terhadap sifat fisik maupun mekanik baja (Vlack, dan Djafrie, 1992).

Paduan baja karbon rendah memiliki sifat antara lain kekerasan sempurna namun tidak kuat dan mudah aus. Oleh karena itu, untuk mendapatkan sifat baja karbon rendah yang tahan aus perlu untuk memperbaiki sifat baja tersebut dengan cara carburizing (Jiang B, 2016). Carburizing merupakan metode yang paling banyak digunakan dalam memperbaiki sifat kekerasan permukaan baja karbon rendah (M.M.A. Bepari, 2016). Ketahanan aus yang baik bisa didapatkan dengan cara memperkuat permukaan. Selain itu, permukaan yang kuat dapat menghasilkan tegangan yang mampu meningkatkan ketahan lelah pada baja (Suh B-S, Lee W-J, 1997).

Salah satu dampak yang sering dialami adalah pembuatan teknologi tepat guna yang berkaitan dengan pemotongan. Untuk mendapatkan pisau yang tajam, biasanya membutuhkan material yang keras. Akan tetapi semakin keras material, maka dia juga semakin mudah patah, dan akan lebih mudah patah. Maka diperlukan material yang mempunyai keuletan yang tinggi, tetapi mempunyai tingkat kekerasan permukaan yang baik juga. Agar permasalahan tersebut dapat diatasi, maka langkah yang dikerjakan adalah melakukan heat treatment pada baja.
Untuk mengatasi hal tersebut, upaya yang dapat dilakukan adalah dengan melakukan proses perlakuan panas pada baja.

Carburizing merupakan metode pengarbonan yang bertujuan untuk mengatasi permasalahan tersebut. Perlakuan panas dengan carburizing diharapkan dapat meningkatkan sifat fisik dan mekanik baja dengan memodifikasi kadar karbon pada permukaan baja. Hal tersebut dapat menghasilkan baja dengan kekerasan permukaan tinggi dan kekerasan yang rendah pada bagian dalam, sehingga material tersebut memiliki keuletan tetap tinggi. Menurut CAO Yan-guang dkk (2016), perlakuan pengerasan permukaan material baja bertujuan untuk membuat komponen penting seperti transmisi gear pada industri otomotif.

Salah satu jenis limbah yang dapat digunakan dalam proses carburizing adalah serbuk gergaji kayu jati. Ketersediaan limbah serbuk gergaji kayu melimpah di alam. Seiring meningkatnya kebutuhan kayu dalam semua lini termasuk pada konstruksi dan furnitur maka ketersediaan limbah kayu juga akan semakin meningkat. Termasuk di dalamnya adalah limbah serbuk gergaji. Berdasarkan pengamatan peneliti, keberadaan serbuk gergaji kayu di daerah Kota Kediri dan sekitarnya belum dapat dimanfaatkan maksimal. Pemanfaatan yang telah dilakukan oleh masyarakat sekitar yaitu sebagai kayu bakar. Bahkan tidak jarang limbah tersebut hanya dibiarkan begitu saja hingga menumpuk menjadi sampah dan mencemari lingkungan. Serbuk gergaji kayu jati merupakan jenis serat alam yang memiliki bentuk partikel. Berdasarkan penelitian Muiz (2005) menyebutkan bahwa massa jenis serat alam sebesar $1,3-1,4 \mathrm{gr} / \mathrm{cm}^{3}$, di mana angka ini hampir sama dengan massa jenis serbuk gergaji.

Kajian tentang perlakuan panas pada baja karbon dengan metode pack carburizing sudah banyak dilakukan, di antaranya oleh Alfani, (2016) meneliti tentang variasi temperature terhadap ketahanan aus pada proses karburasi baja ST 41. Kemudian Sudiro, (2013) meneliti variasi waktu tahan terhadap tingkat kekerasan dan keausan baja karbon rendah. Selanjutnya Setiamarga dkk, (2006) meneliti sprocket sepeda motor dengan material baja karbon rendah pada proses pack carburizing. Dari beberapa penelitian di atas mengindikasikan bahwa penelitian tentang perlakuan panas terhadap baja karbon khususnya metode pengerasan terus dikembangkan untuk memenuhi karakteristik baja sesuai dengan yang diharapkan. Peningkatan sifat mekanik material logam merupakan hal yang perlu diperhatikan. Semakin banyak jumlah karbon aktif pada proses karburasi, maka akan meningkatkan nilai kekerasan material dengan holding time paling rendah (Rahma dkk, 2017).

Berdasarkan hal tersebut, maka dalam penelitian ini bertujuan untuk mendapatkan komposisi tepat dari baja karbon rendah yang dapat diimplementasikan untuk pembuatan pisau TTG 
yang tajam namun juga tidak mudah patah. Penelitian ini dilaksanakan di laboratorium material Politeknik Negeri Malang di kota Kediri. Variabel penelitian ini adalah suhu, waktu penahanan, media carburizing

\section{Metode Penelitian}

Kerangka jalannya penelitian akan dijabarkan pada gambar berikut.

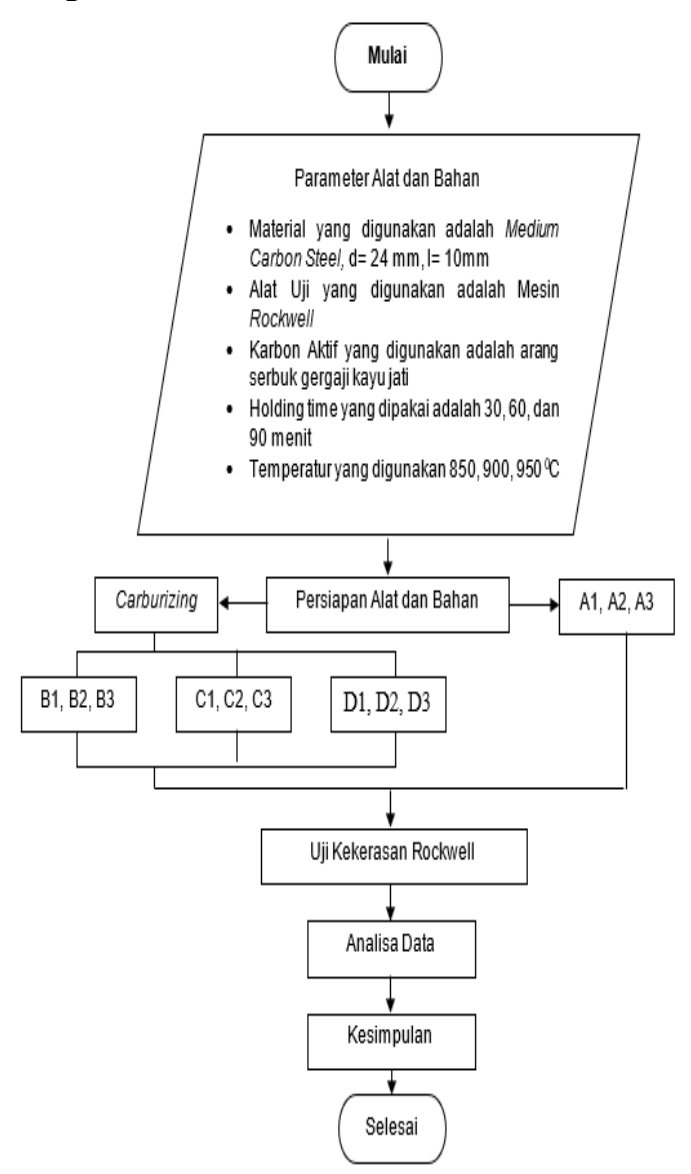

Gambar 1. Diagram alir

Pelaksanaan penelitian ini dilaksanakan di laboratorium material Politeknik Negeri Malang PSDKU Kediri. Populasi dari penelitian ini adalah suhu, waktu penahanan, media carburizing. Sedangkan sampelnya adalah suhu $850^{\circ} \mathrm{C}, 900^{\circ} \mathrm{C}$, dan $950^{\circ} \mathrm{C}$, waktu penahanan 30 menit, 60 menit, dan 90 menit, serta media carburizing serbuk gergaji kayu jati. Variabel tetap dalam penelitian ini adalah low carbon steel, media karburasi arang serbuk gergaji kayu jati, sedangkan variabel bebasnya adalah variasi temperature dan holding time. Selanjutnya pengujian dilakukan untuk mengetahui sifat mekanik sampel. Pembentukan benda kekerasan dilakukan secara manual dengan memotong komposit menggunakan alat potong. Alat yang digunakan untuk melakukan uji kekerasan adalah Rockwell TH550. Spesimen baja karbon rendah dalam penelitian ini dibentuk sesuai gambar berikut.
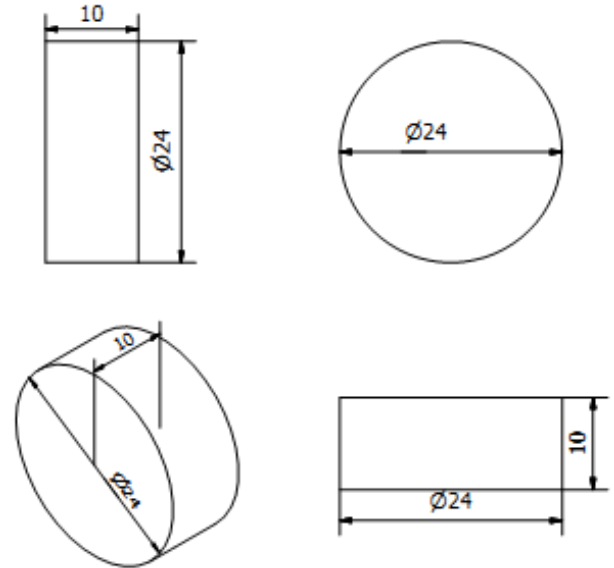

Gambar 2. Dimensi spesimen (mm)

Gambar 2 dimensi spesimen, merupakan ukuran dan bentuk spesimen yang digunakan dalam penelitian ini. Spesimen yang dipakai berupa baja karbon rendah dengan bentuk lingkaran dan memiliki diameter $24 \mathrm{~mm}$ serta tebal $10 \mathrm{~mm}$.

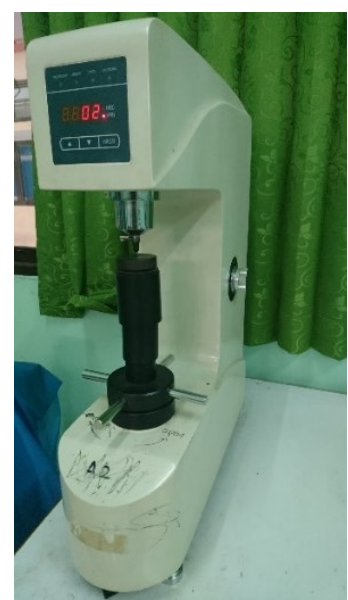

Gambar 3. Alat uji kekerasan rockwell TH550

Pengumpulan data dilakukan dengan cara eksperimen untuk mengumpulkan data utama pada percobaan di laboratorium dan data tambahan dari peneliti-peneliti lain. Data didapatkan dengan cara pengujian kekerasan permukaan spesimen setelah melalui proses carburizing. Kemudian, analisa data yang digunakan adalah teknik analisis statistik deskriptif, di mana data mentah yang diperoleh dari pengujian diolah dalam persamaan nilai tengah sebagai berikut:

Nilai Tengah $=\frac{\sum N}{N}$

Keterangan:

$\sum_{\mathrm{N}} \mathrm{N}=$ Nilai akhir setiap spesimen

$\mathrm{N} \quad=$ Jumlah spesimen

Data yang dihasilkan berupa data yang kuantitatif yang mengimplementasikan perbandingan 
antara data logam raw materials, dan logam decarburizing.

Dalam rangka mempermudah proses pengamatan interpretasi hasil penelitian, maka berikut disajikan lembar pengamatan uji kekerasan Rockwell.

Tabel 1. Lembar Pengamatan

\begin{tabular}{|c|c|c|c|c|}
\hline \multicolumn{5}{|c|}{ Data Hasil Nilai Uji Kekerasan } \\
\hline \multirow{2}{*}{ No. } & \multirow{2}{*}{ Temperature } & \multicolumn{3}{|c|}{ Holding Time (menit) } \\
\hline & & 30 & 60 & 90 \\
\hline \multirow[t]{2}{*}{1} & $850^{0} \mathrm{C}$ & A1 & A2 & A3 \\
\hline & $900{ }^{0} \mathrm{C}$ & $\mathrm{B} 1$ & B2 & B3 \\
\hline 3 & $950{ }^{0} \mathrm{C}$ & $\mathrm{C} 1$ & $\mathrm{C} 2$ & $\mathrm{C} 3$ \\
\hline
\end{tabular}

Keterangan:

A1 : Spesimen diberi perlakuan carburizing dengan temperature $850^{\circ} \mathrm{C}$ variasi holding time 30 menit

A2 : Spesimen diberi perlakuan carburizing dengan temperature $850^{\circ} \mathrm{C}$ variasi holding time 60 menit

A3 : Spesimen diberi perlakuan carburizing dengan temperature $850^{\circ} \mathrm{C}$ variasi holding time 90 menit

B1 : Spesimen diberi perlakuan carburizing dengan temperature $900^{\circ} \mathrm{C}$ variasi holding time 30 menit

B2 : Spesimen diberi perlakuan carburizing dengan temperature $900^{\circ} \mathrm{C}$ variasi holding time 60 menit

B3 : Spesimen diberi perlakuan carburizing dengan temperature $900^{\circ} \mathrm{C}$ variasi holding time 90 menit

C1 : Spesimen diberi perlakuan carburizing dengan temperature $950^{\circ} \mathrm{C}$ variasi holding time 30 menit

C2 : Spesimen diberi perlakuan carburizing dengan temperature $950^{\circ} \mathrm{C}$ variasi holding time 60 menit

C3 : Spesimen diberi perlakuan carburizing dengan temperature $950^{\circ} \mathrm{C}$ variasi holding time 90 menit

\section{HASIL DAN PEMBAHASAN}

Salah satu upaya yang digunakan untuk melakukan perbaikan sifat mekanis material untuk mendapatkan material sesuai dengan karakteristik yang diinginkan adalah menggunakan proses carburizing merupakan (Rahma, dkk, 2017). Sampel yang digunakan dalam penelitian ini terdiri dari beberapa sampel dengan masing-masing sampel dilakukan replikasi minimal tiga kali. Tujuan pengulangan dan replikasi adalah untuk mendapatkan hasil yang lebih presisi. Pengujian dilakukan sebanyak tiga kali dan diambil rata-rata dari setiap pengujian sesuai dengan gambar 4 .
Data Hasil Nilai Uji Kekerasan

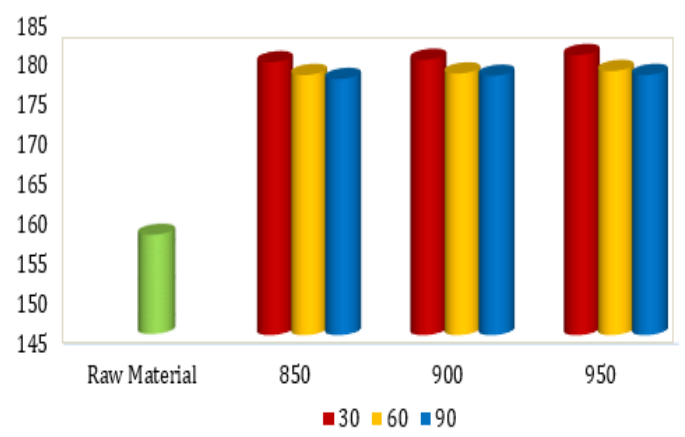

Gambar 4. Nilai kekerasan pada pengujian material

Hasil pengujian kekerasan di atas memperlihatkan bahwa terdapat nilai kekerasan yang paling rendah pada raw material (158.3 HRB (Hardness Rockwell B)). Dalam hal ini menunjukkan bahwa carburizing dan holding time mempunyai kontribusi terhadap peningkatan kekerasan material. Sedangkan pada material yang sudah diberikan perlakuan, nilai kekerasan yang paling rendah terdapat pada spesimen A3 (177.1 HRB (Hardness Rockwell B)). Pada spesimen ini diberi perlakuan holding time paling lama dan variasi temperature paling rendah. Rendahnya nilai kekerasan permukaan disebabkan adanya difusi karbon yang masuk terlalu dalam ke spesimen karena waktu holding time yang lama. Semakin lama holding time pada proses karburasi akan menyebabkan unsur karbon berdifusi ke dalam spesimen. Hal ini menyebabkan permukaan nilai kekerasan permukaan spesimen menjadi rendah jika dibandingkan dengan waktu penahanan yang rendah.

Hasil nilai uji kekerasan spesimen tertinggi terdapat pada spesimen B1 (180.1 HRB (Hardness Rockweel B)). Spesimen ini mengalami perlakuan holding time paling rendah dan temperature pada $900^{\circ} \mathrm{C}$. Spesimen C1 $(179,5$ HRB (Hardness Rockweel B)) menempati posisi kedua tertinggi setelah spesimen B1. Di mana spesimen C1 juga mendapatkan perlakuan holding time paling rendah pada temperature $950^{\circ} \mathrm{C}$. Hasil seperti ini juga didapatkan pada penelitian yang dilakukan oleh Rahma, dkk (2017), di mana nilai kekerasan permukaan paling tinggi terdapat pada holding time yang terendah.

Nilai hasil uji kekerasan permukaan pada Gambar 5 dan Gambar 6 memperlihatkan bahwa setiap spesimen memiliki nilai kekerasan yang berbeda-beda. Tinggi rendahnya holding time yang dilakukan pada proses carburizing mengakibatkan perbedaan nilai kekerasan permukaan spesimen. 


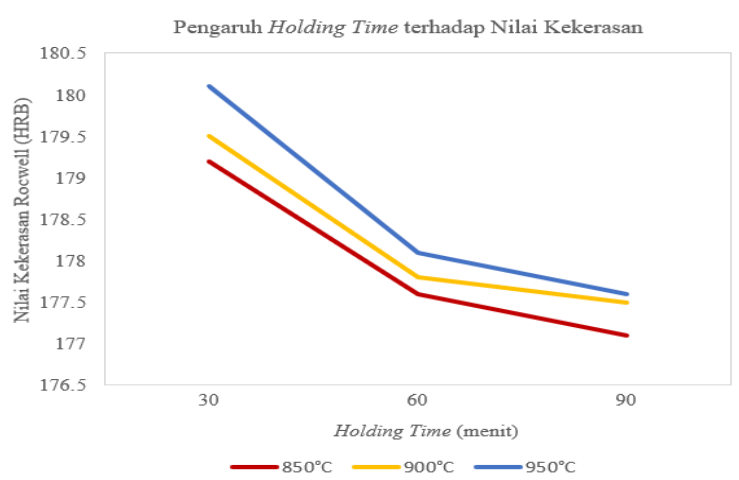

Gambar 5. Grafik pengaruh holding time carburizing terhadap nilai kekerasan

Pada grafik tersebut diperlihatkan bahwa nilai kekerasan tertinggi didapatkan pada holding time selama 30 menit jika dibandingkan dengan holding time selama 60 dan 90 menit. Begitu juga dengan holding time selama 60 menit menunjukkan nilai kekerasan permukaan yang lebih tinggi jika dibandingkan dengan nilai holding time selama 90 menit. Nilai kekerasan permukaan tersebut menurun seiring dengan bertambahnya waktu holding time. Hasil nilai kekerasan seperti ini disebabkan karena karbon aktif yang digunakan dalam proses carburizing yang berdifusi ke dalam spesimen, sehingga permukaan material mendapatkan karbon aktif lebih sedikit dan hal ini mengakibatkan nilai uji kekerasan permukaan spesimen menjadi rendah.

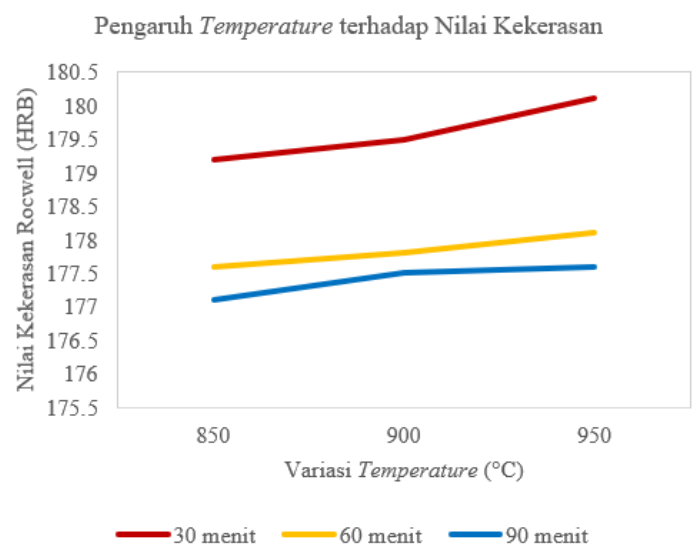

Gambar 6. Grafik pengaruh temperature carburizing terhadap nilai kekerasan permukaan

Nilai uji kekerasan permukaan pada temperature holding time $950^{\circ} \mathrm{C}$ menunjukkan nilai paling tinggi dari nilai uji kekerasan pada temperature $900^{\circ} \mathrm{C}$ dan $850^{\circ} \mathrm{C}$ pada semua variasi holding time. Begitu juga sebaliknya, nilai uji kekerasan permukaan pada temperature holding time $850^{\circ} \mathrm{C}$ menunjukkan nilai paling rendah dari nilai uji kekerasan pada temperature $900^{\circ} \mathrm{C}$ dan $950^{\circ} \mathrm{C}$ pada semua variasi holding time. Nilai uji kekerasan paling tinggi terdapat pada temperature tertinggi $\left(950^{\circ} \mathrm{C}\right)$ dan waktu penahanan paling rendah (30 menit).
Sedangkan nilai uji kekerasan terendah terletak pada temperature tertinggi $\left(950^{\circ} \mathrm{C}\right)$ dan holding time terendah 30 menit. Dalam penelitiannya, Sudiro (2013) juga menyimpulkan bahwa temperature carburizing berperan terhadap nilai uji kekerasan permukaan karbon rendah. Semakin rendah temperature carburizing maka semakin rendah pula nilai uji kekerasan permukaannya.

\section{KESIMPULAN DAN SARAN}

Nilai uji kekerasan tertinggi terdapat pada holding time selama 30 menit dengan temperature carburizing $950^{\circ} \mathrm{C}$ dengan nilai 180.1 HRB. Sedangkan nilai uji kekerasan terendah terdapat pada holding time selama 90 menit dengan temperature carburizing $850^{\circ} \mathrm{C}$ dengan nilai $177.1 \mathrm{HRB}$.

\section{UCAPAN TERIMA KASIH}

Ucapan terimakasih peneliti sampaikan kepada Politeknik Negeri Malang sebagai institusi tim peneliti terutama kepada bagian UPT P2M yang telah memberikan kepercayaan dan kesempatan kepada peneliti untuk melaksanakan program penelitian ini.

\section{DAFTAR PUSTAKA}

Akita, M., Tokaji, K. 2006. Effect Of Carburizing On Notch Fatigue Behavior In Aisi 316 Austenitic Stainless Steel. Surface And Coatings Technology. 200(20) : 6073-6078

Alfani, W. (2016). Pengaruh Variasi Temperatur Pada Proses Pack Carburizing Terhadap Ketahanan Aus Baja St 41. Skripsi S1 Jurusan Teknik Mesin Universitas Lampung

Amanto, Hari Dan Daryanto. 2003. Ilmu Bahan. Jakarta: Bumi Aksara.

Amstead, B, H., Phillip F. Ostwald Dan Myron L. Begeman. 1997. Mekanik Jilid I Edisi Ketujuh Versi S1. Jakarta: Erlangga.

Cao, Y, G., Xu, L., Zhang, G, Q., Shi, J., Wang, M, Q. 2016. Rolling Contact Fatigue Properties Of Sae 8620 Steel After Case Carburizing. Journal Of Iron And Steel Research, International. 23(7) : 711-716

Jiang, B. High Toughness And Multiphase Microstructure Transition Product Of Carburizing Steel By A Novel Heat Treatment Cooling Process. 675: 361-370, 2016

Malau, Viktor Dan Khasani. 2008. Karakterisasi Laju Keausan Dan Kekerasan Dari Pack Carburizing Pada Baja Karbon Aisi 1020. Jurnal Media Teknik. Tahun Xxx, No.3, 367374.

Muiz, A. 2005. Pemanfaatan Batang Pisang (Musa Sp) Sebagai Bahan Baku Papan

Nanulaitta, Nevada J. M Dan Eka. R. M. A. P. Lillipaly. 2012. Analisa Sifat Kekerasan Baja St-42 
Dengan Pengaruh Besarnya Butiran Media Katalisator (Tulang Sapi (Caco3)) Melalui Proses Pengarbonan Padat (Pack Carburising). Jurnal Teknologi. Vol. 9, No. 1, 985-994.

Rahma, R, S., Suheni, Dani Darojat, I. Pengaruh Variasi Karbon Aktif Dan Waktu Tahan Terhadap Kekerasan Material Jis G-3123 Menggunakan Metode Pack Carburizing. R.E.M. (Rekayasa Energi Manufaktur) Jurnal. Vol 2. No. 1 : 153162. 2017

Setiamarga, B, H., Kurniawati, N., Dan Rumendi, U. (2006). Pack Carburizing Pada Sprocket Sepeda Motor Dengan Material Baja Karbon Rendah. Jurnal Teknik Mesin. Vol 21. No.1.

Sudiro. (2013). Studi Pengaruh Carburizing Baja Karbon Rendah Dengan Media Arang Dan Vareasi Holding (Penahanan Suhu) Terhadap Tingkat Kekerasan Dan Keausan. Jurnal Autindo Politeknik Indonusa Surakarta. Vol. 1, No. 1.

Sugiyono. 2010. Metode Penelitian Pendidikan Pendekatan Kuantitatif Kualitatif, Dan R\&D. Bandung: Alfabeta.

Suh B-S, Lee W-J. 1997. Surface Hardening Of Aisi 3161 Stainless Steel Using Plasma Carburizing. Thin Solid Films. 295: 185-92

Surdia, T., Dan Saito. S. (992). Pengetahuan Bahan Teknik, Jakarta: Pradnya Paramita

Surdia, Tata Dan Shinroku Saito. 1992. Pengetahuan Bahan Teknik. Jakarta: Pradnya Paramita.

Vlack, V, Dan Djafrie, S. (1992). Ilmu Dan Teknologi Bahan. Jakarta: Erlangga 